\title{
A New Discourse about Moving Photography as a Static Visual Narration
}

\author{
Eko Budhi Susanto', Yasraf Amir Piliang ${ }^{2}$, and Setiawan Sabana ${ }^{3}$ \\ ${ }^{123}$ Institut Teknologi Bandung, Indonesia \\ ${ }^{1}$ ekobudhisusanto@fsrd.itb.ac.id, ${ }^{2}$ ya_piliang@gmail.com, \\ ${ }^{3}$ setiawansabana@yahoo.com
}

\begin{abstract}
Entering the digital age, photography has developed very rapidly. One of which underwent major change was its form. The digital age offers a new form that is detached of the material aspects. Photography is no longer a physical object but an image as a data code that can be represented in various forms both printed or non-printed. The loss of physical form presents new possibilities in photography, for example, more easily manipulated, reproduced, and transmitted. Another thing is that non-physical photography allows loading several frames in one image. A new problem arises, which is blurring the boundaries between photography and cinema. This paper,through literature studies tries to explore the extent to which photographic works have developed today so as to look like cinema, and look for new boundaries between photography and cinema. So far, photographic works that have active motion elements (changing frame) are cinemagraph and boomerang. Both of them look like cinema, but using visual narrative categorization, it can be clearly traced that they are included in the photography category which is has static visual narrative characteristics. This paper finally coined the new term moving photography to distinguish it from conventional photography which had already existed and is even still common today.
\end{abstract}

Keywords: cinema, cinemagraph,moving photography, image, static visual narration.

\section{INTRODUCTION}

The word photography comes from two Greek terms, 'photo', which comes from the word phos (light) and 'graphy' which comes from the word graphe (writing or drawing). Thus the literal definition of photography is to write or draw using light. From these two words, the identity of photography can be translated by a combination of something natural (light) with practices formed from human culture (writing or drawing).

Research on the projection of light and light-sensitive medium was carried out in the 17th and 18th centuries, and even long before (In the 10th century Ibn Al-Haytam accidentally discovered the principle of optical work). However, the conception of photography that became the forerunner to modern photography was initiated by William Henry Fox Talbot in the early 19th century through his discovery, a device for recording light called camera obscura. This discovery is in line with the spirit of the industrial revolution which at that time was made the European nations competing to conquer the world, explore and record 
everything outside Europe. At the end of the 18th century to the beginning of the 19th century there were at least 18 other names besides Talbot in Europe and the United States that conducted research to produce images using light $[1$, pp. 5, 8].

As soon as its founded, photography changed the view of human culture, which was previously dominated by nature slowly began to dominate nature. The birth of photography is a turning point for people to get to know nature and share it with others. Photography technology and culture have evolved with changing times, even the identity of photography itself. Even so, characteristics of photography remains the same, as explained in The Photographer's Eye, these arethe thing itself, the detail, the frame, time, and vantage point $[2$, pp. 6-11].The thing itself refer to photographic ability to record what is in front of the lens, the detail refer to photography's focuses on pieces of reality to tell something, the frame refer to the relationship between elements in the picture as a result of selection and elimination of reality or photographic framing, time refer to the effect of the duration of the exposure time on the resulting image, vantage point refer to the angle from which the photo was taken.

Even though the characteristics remains the same, digital era has major change to the form of photography. As a digital file, photographic works no longer depend on material objects. New problems arise when photographic works contain more than one frame in an image. Its now has dimension of time that makes the boundary between photography works and cinema works is blurredthrough the analysis of narrative aspects, this paper tries to categorize new term in photography, namely moving photography, to distinguish it from still photography and cinema.

\section{LITERATURE REVIEW}

The literature review firstly will examine dematerialization in photography, especially digital photography, then discuss the limiting phenomena between photography and cinema. This paper will further investigate the cinemagraph as a concept and phenomenon of digital photography to finally showingmoving photography.

\subsection{Dematerialization of digital photography}

Photography previously refer as an object, it is an emotional object that gives satisfaction, its loss could causes sadness. Barthes even saw photography as a living creature that can aged so that it eventually became damaged[3, p. 93]. In the digital era, photography as a medium go through a process called 'dematerialization'. By dematerialization means digital photography is no longer a physical object that always involves paper or light-sensitive plates. Its rather a collection of data codes stored in electronic storage media in the form of binary numbers that when "opened" will represent an image through a series of computations (on a computer, digital camera, cell phone, etc.) and display it on the screen. In addition, its non-physical nature enables digital photography to be easily changed in contents, then produced, reproduced, transmitted digitally, and does not need to be printed. According to Sassoon, digital photography that has never been printed (only in digital form) can be seen as a truer version of photography (writing using light) than photography that requires physical media to display its image in the form of material [4, p. 196]. Therefore, the idea of photography before, which is still related to physical objects needs to be re-evaluated in the digital age.

It can be concluded that photography in the digital era is no longer a physical object involving photo paper, film plates, negatives, etc., but rather in the form of a visual image, which is a representation of reality that requires the visual senses / vision to perceive it. The 
media itself can be chosen later by the artist or the photographer, because it is no longer the center of the idea of photography itself[5, p. xiii].

The loss of physical objects from photographic identity presents new problems, but also new many possibilities. Digital photography is no longer a physical object but a simulation on the screen. If previously the reality of photography only included physical objects (material form) that filled the dimensions of space, now, in digital era photography did not actually have a physical form, but might have filled dimension of time. In other way we could say digital photography might have duration because when dimension of space is no longer a limitation in photography, it is possible to use screens to display multiple frames in one photographic image. This lead to blurring the strict line between photography and cinema.

This kind of photography at first similar to the initial conception of film and cinema (moving picture). The differences to today's film or cinema is that these kind of photography has no concept of succession of events or sequences of events [6, p. 25]. The easiest example is like a photograph in a newspaper in Harry Potter movies.

\subsection{Cinemagraph}

Cinemagraph was first made by a photographer from New York named Jamie Beck who worked with web designer Kevin Burg in 2011. Beck and Burg first made cinemagraph at the Fashion Week 2011 in New York, spending 1 to 2 days to produce work that tells about Anna Wintour from Vogue magazine examining the catwalk, or about fluttering hair models[7]. Immediately people fell in love with Beck and Burg's works, and that inspiring them to produce various other works and conducting various experiments to produce more spectacular cinemagraph works, also not forgetting to publish the new term cinemagraph as their findings[8]. Even so, it turned out that cinemagraph had existed 4 decades ago. At 1980, David Bowie had made a cinemagraph that aired at minute 0:33 - 1:25 in his video clip titled "Ashes to Ashes"[9].

in some papers, cinemagraph is said to be a combination of photography and cinema. In his paper, Erol said cinemagraph as a hybrid form of photography and cinema, and relate to digital technology [10]. Chiarini said cinemagraph represents a hybrid, a paradoxically animated photographic image, obtained via the use of techniques originating in photography, cinema, video and collage [11]. Both Erol and Chiarini agreed to see cinemagraph as innovation in photography. Bai and friends in his paper, too, sees cinemagraph from photography point of view, as photographic image that lend (partly) dynamic frame changing to make portraiture cinemagraph[12].

\section{MOVING PHOTOGRAPHY}

From the literatures mention about cinemagraph in this paper, at first they argue if cinemagraph is a hybrid of photography and cinema. But in the end, they all agreed that cinemagraph is innovation of digital photography. The inventors, Beck and Burg also claim that cinemagraph is a live image, a photographic works that contains moving elements (not as a result of the exposure time duration as said by Szarkowski) to repeat smoothly to create a moment of movement that never ends. What's interesting in cinemagraph works is that viewers can feel as though they are trapped in a frozen time and only repeats in the same moment, even some part(s) of the moment that move repeatedly, the others are freeze. This surreal and hypnotic experience is at least offered by the cinemagraph. 
Although it has been 8 years since the term cinemagraph was coined, the term moving photography is not yet defined, thus the blurred line between digital photography and cinema has not been solved. Aproaching through narration aspect of a visual media, this paper trying to categorize cinemagraph into photography instead of cinema, then coined new term in photography, namely moving photography.

The namemoving photography is to distinguish it from the term stop-motion photography which is basically means freezing movement within the photographic frame, and motionpicture with photography which means creating an impression of motion in the photographic frame [10]. Both produce still images, although stop-motion photography then combines all the frames and moves them to make a clip or cinema. Moving photography in this paper refer to motion in photographic image because of frame changing.Moving photography by its frame changing mode give a sensation like an attempt to get out of the photography's trap of space and time, which is repeated forever in the same moment. Cinemagraphs especially, has a partly moving, partly frozen image at the same time gives a comfortable and strange sensation.

Another example of moving photographyis the boomerang from Instragram. Boomerang is a very short video clip that is repeated (loop) or back and forth/forward backward (bounce) and is usually shared via social media[9]. Boomerang clips are created using the Boomerang application and are (usually) uploaded to the Instagram story feature. If the cinemagraph movement is only seen in one or several elements in the frame (technically by use masking feature in part of still frame, usually first frame), the boomerang advanced the entire frame to the next frame according to the time flow of the clip. Boomerang clip trend is bounce or back and forth, so that the object seems to move and then retreat back to the starting point, and the clip will looping from the beginning to the end then back again to the starting point, and so on. Boomerang offers a more lively photo sensation by making the real movements image that still photographic image offers in viewer's mind.

\section{VISUAL NARRATIVE ASPECTS IN MOVING PHOTOGRAPHY}

As a visual works, photography is very possible to contain narrative elements in it. Narrative is different from story. The story is defined as the sequence of events while the narrative focuses on a story. Therefore the narrative does not always have to be related to the duration of time. In their paper in the Design Thoughts Journal, Pimenta and Poovaiah explain more about static visual narratives, dynamic visual narratives, and interactive visual narratives[13, pp. 29-43]. To clarify the boundaries between photography, moving photography and cinema, can be seen from its visual narrative character. Table 1 will explain the strict boundaries between the those three in different distinguishing characteristics. These characteristics will categorize the three into Static Visual Narrative (SVN) or Dynamic Visual Narrative (DVN).

Table 1. Visual narrative aspect of photography, moving photography, and cinema.

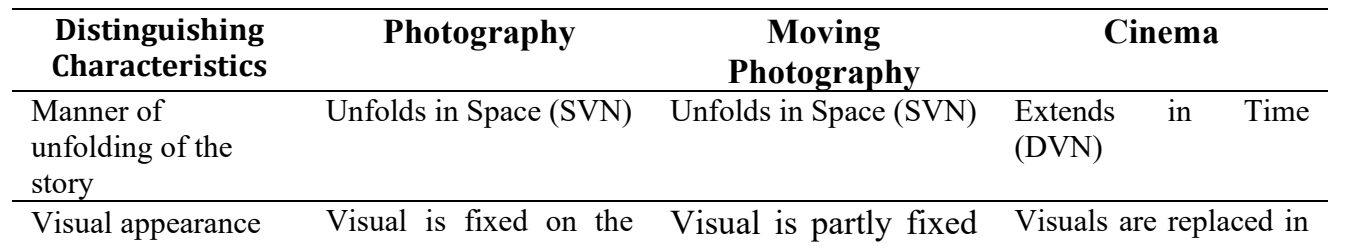




\begin{tabular}{|c|c|c|c|}
\hline & surface of the medium & partly replaced & rapid succession at the \\
\hline & $(\mathrm{SVN})$ & $\begin{array}{l}\text { (cinemagraph) or } \\
\text { replaced in rapid } \\
\text { succession at the } \\
\text { same space } \\
\text { (boomerang) but only } \\
\text { consist of 1 scene }\end{array}$ & same space (DVN) \\
\hline $\begin{array}{l}\text { Knowledge of the } \\
\text { story }\end{array}$ & $\begin{array}{l}\text { SVN's bank on the } \\
\text { prior knowledge of the } \\
\text { story (SVN) }\end{array}$ & $\begin{array}{l}\text { SVN's bank on the } \\
\text { prior knowledge of the } \\
\text { story (SVN) }\end{array}$ & $\begin{array}{l}\text { The viewer does not } \\
\text { need to know the story } \\
\text { prior to viewing } \\
(\mathrm{DVN})\end{array}$ \\
\hline $\begin{array}{l}\text { Visual and Viewer } \\
\text { Interaction }\end{array}$ & $\begin{array}{l}\text { The visual is fixed but } \\
\text { the viewer } \\
\text { (imagination) is mobile } \\
(\mathrm{SVN})\end{array}$ & $\begin{array}{l}\text { Both the viewer } \\
\text { (imagination) and the } \\
\text { visual is moving (or } \\
\text { partly moving) in } \\
\text { forever loop. }\end{array}$ & $\begin{array}{l}\text { The visuals move but } \\
\text { the viewer is at a fixed } \\
\text { location (DVN) }\end{array}$ \\
\hline Speed of Viewing & $\begin{array}{l}\text { The spectator can } \\
\text { decide the speed of } \\
\text { viewing }(\mathrm{SVN})\end{array}$ & $\begin{array}{l}\text { The spectator can } \\
\text { decide the speed of } \\
\text { viewing (SVN) because } \\
\text { its stuck in forever loop. }\end{array}$ & $\begin{array}{lr}\text { Speed of viewing } \\
\text { predetermined } \\
\text { creator }(\mathrm{DVN})\end{array}$ \\
\hline $\begin{array}{l}\text { Sequence of } \\
\text { Viewing }\end{array}$ & $\begin{array}{l}\text { The spectator can } \\
\text { manipulate } \\
\text { sequence and the pace } \\
\text { of viewing (SVN) }\end{array}$ & $\begin{array}{l}\text { The spectator can } \\
\text { manipulate the } \\
\text { sequence and the pace } \\
\text { of viewing (SVN) } \\
\text { because its stuck in } \\
\text { forever loop. }\end{array}$ & $\begin{array}{l}\text { The spectator has no } \\
\text { control over the } \\
\text { sequence or pace of } \\
\text { viewing (DVN) }\end{array}$ \\
\hline Contemplation time & $\begin{array}{l}\text { Viewer has ample } \\
\text { contemplation time } \\
(\mathrm{SVN}) \\
\end{array}$ & $\begin{array}{lr}\begin{array}{l}\text { Viewer has } \\
\text { contemplation } \\
(\mathrm{SVN})\end{array} & \begin{array}{r}\text { ample } \\
\text { time }\end{array} \\
\end{array}$ & $\begin{array}{ll}\text { Contemplation } & \text { time } \\
\text { restricted (DVN) } & \end{array}$ \\
\hline $\begin{array}{l}\text { Perception of } \\
\text { Movement in the } \\
\text { VN }\end{array}$ & $\begin{array}{l}\text { Movement results from } \\
\text { active participation of } \\
\text { the viewer (SVN) }\end{array}$ & $\begin{array}{l}\text { Movement result in } \\
\text { frame partly } \\
\text { (cinemagraph) or } \\
\text { fully causes by the } \\
\text { rapid change of } \\
\text { visual, but stuck on } \\
\text { forever loop. }\end{array}$ & $\begin{array}{l}\text { Movement is due to } \\
\text { the rapid change of } \\
\text { visuals (DVN) }\end{array}$ \\
\hline
\end{tabular}

\subsection{Moving photography as a Static Visual Narrative}

From those table, Photography is clearly included in the category of static visual narrative while cinema is included in the category of dynamic visual narrative.Moving photography, seeing examples of cinemagraph and boomerang, contains more SVN characters even though in some aspects they very much alike DVN characteristics. In moving photography, although its have a duration of time, the disclosure of the story takes place in a dimension of space, while the dimension of time more often functioning as an aesthetic aspect, sweetener, or gimmick element that provokes viewers to stare longer at the works. Visual appearance in moving photography same as in dynamic visual narration (in boomerang) or partially static (in cinemagraph) but both take place in a very short time and only has one scene.To gain knowledge about in-depth stories in moving photography, the viewer needs to have 
knowledge about the background of the story because visuals only provide signifiers, and it will be more cleary if accompanied by caption like in still photography works. Regarding visual and viewer interaction, moving photography's visuals have movements, but viewers are given the freedom to imagine the movements, or story lines (in this case the beginning and end). Moving photography, like still photography, not telling through the dimension of time but through chosen moments or what Henri Cartier-Bresson calls a decisive moment, that is, a choice of moment that represents the beginning, middle and end of a scene / story / narration[1, p. 18].Regarding the speed of viewing and the order of viewing, in moving photography the viewer can decide the pace and the sequence of viewing well as in SVN (still photography) because of the short and repetitive duration of time (forever looping).Moving photography too, gives viewers the freedom of time to contemplate these visual contents as well as in SVN. Perception of movement in moving photography is partly (in cinemagraph) or fully (in boomerang) by the rapid change of visual, but on forever loop.

From discussion above, its clear that altough having its frame changing in appearance, moving photography has static visual narrative characteristics. Its dimension of time and rapid visual changing different from true dynamic visual narrative characteristics, thus its very different from cinema.

\section{CONCLUSION}

Although the cinemagraph and boomerang works blurred the boundary between still photography and cinema, but through a visual narrative approach, it is clear that both works present the narrative aspect alike still photography does which match static visual narrative characteristics. Still, it has differences from still photography, which is its dimension of time. Therefore this paper firmly concludes cinemagraph and boomerang as one of the future alternatives of photography in the digital era where print media is no longer the only way to present photographic images but there are other media that are more flexible such as digital files that are presented on the screen. To differentiate it from conventional photography which presents still images, this paper specifically refers cinemagraph and boomerang works as moving photography, which is photographic works that present photographic images that have an element of movement (displacement of frames) in it.

\section{REFERENCES}

[1] S. Bull, Photography. New York: Routledge, 2010.

[2] J. Szarkowski, The Photographer's Eye. New York: The Museum of Modern Art, 2007.

[3] R. Barthes, Camera Lucida : Reflections on Photography. New York: Hill and Wang, 1981.

[4] J. Sassoon, "Photographic Materiality in the Age of Digital Reproduction," in Photographs, Objects, Histories: On the Materiality of Images, E. Edwards and J. Hart, Eds. Abingdon: Routledge, 2004.

[5] W. J. T. Mitchell, What pictures want? London: Tne University of Chicago Press, Ltd., 2005.

[6] G. Genette, Gerard Genette Narrative Discourse An Essay in Method. New York: Cornell University Press, 1983.

[7] E. Flock, "Cinemagraphs: What It Looks Like When a Photo Moves," The Washington Post, 2011. [Online]. Available: https://www.washingtonpost.com/blogs/blogpost/post/cinemagraphs-what-it-looks- 
like-when-a-photo-moves/2011/07/08/gIQAONez3H_blog.html. [Accessed: 03-Oct2019].

[8] J. Beck and K. Burg, "Cinemagraphs," Cinemagraphs. [Online]. Available: http://cinemagraphs.com/about/. [Accessed: 05-Oct-2019].

[9] Peter, "The History of Cinemagraphs Includes David Bowie," Flixel. [Online].

Available: https://blog.flixel.com/history-of-cinemagraphs/. [Accessed: 07-Oct-2019].

[10] E. Erol, "Fotoğrafta Hareket Bağlamında Sinemagraf Tekniğinin Değerlendirilmesi," Yedi, pp. 47-53, 2016.

[11] A. Chiarini, "The Multiplicity of the Loop: The Dialectics of Stillness and Movement in The Cinemagraph," Comun. Soc. J. Media, Perform. Arts Cult. Stud., vol. 1, no. Snapshot Culture. The Photographic Experience in the Post-Medium Age, pp. 87-92, 2016.

[12] J. Bai, A. Agarwala, M. Agrawala, and R. Ramamoorthi, "Automatic cinemagraph portraits," Comput. Graph. Forum, vol. 32, no. 4, pp. 17-25, 2013.

[13] S. Pimenta and R. Poovaiah, "On Defining Visual Narratives," Des. Thoughts, vol. 3, pp. 25-46, 2010. 